\title{
Mycobacterium phlei cell wall complex directly induces apoptosis in human bladder cancer cells
}

\author{
MC Filion ${ }^{1,2}$, P Lépicier $^{1}$, A Morales $^{3}$ and NC Phillips ${ }^{1,2}$ \\ ${ }^{1}$ Faculté de Pharmacie, Université de Montréal, Montréal, Québec H3C 3J7, Canada; ${ }^{2}$ Bioniche, London, Ontario N6M 1A3, Canada; ${ }^{2}$ Department of Urology, \\ Queen's University, Kingston General Hospital, Kingston, Ontario K7L 2V7, Canada
}

\begin{abstract}
Summary Intact mycobacteria and mycobacterial cell wall extracts have been shown to inhibit the growth of human and murine bladder cancer. Their mechanism of action is, however, poorly understood. Mycobacterium phlei mycobacterial cell complex (MCC) is a cell wall preparation that has mycobacterial DNA in the form of short oligonucleotides complexed on the cell wall surface. In this study, we have investigated the possibility that MCC has anti-cancer activity that is mediated by two different mechanisms - a direct effect on cancer cell proliferation and viability and an indirect effect mediated by the production of interleukin 12 (IL-12), a cytokine known to possess anti-cancer activity. We have found that, although MCC is a potent inducer of IL-12 and IL-6 synthesis in monocytes and macrophages either in vitro or in vivo, it is unable to induce the synthesis of either IL-12, IL-6 or granulocyte-macrophage colony-stimulating factor (GM-CSF) by the human transitional bladder cancer cell lines HT-1197 and HT-1376. MCC is not directly cytotoxic towards these cancer cells, but induces apoptosis as determined by nuclear DNA fragmentation and by the release of nuclear mitotic apparatus protein. Mycobacterium phlei DNA associated with MCC is responsible for the induction of apoptosis. Our results indicate that MCC directly effects bladder cancer cells by inhibiting cellular proliferation through the induction of apoptosis, and has the potential for an indirect anti-cancer activity by stimulating cancer-infiltrating monocytes/macrophages to synthesize IL-12.
\end{abstract}

Keywords: apoptosis; bladder cancer cells; mycobacterial cell wall; granulocyte-macrophage colony-stimulating factor interleukin 6; interleukin 12

Intravesical treatment of superficial bladder cancer with live bacillus Calmette-Guérin (BCG) is an effective anti-cancer immunotherapy (Morales, 1984). However, the use of live BCG organism has been associated with serious undesirable side-effects such as fever, serum sickness-like syndromes, granulomatous infection, sepsis and even death (Lamm et al, 1992). Variability in viability and immunogenicity are other disadvantages associated with the use of live bacteria as immunotherapeutic agents (Lagranderie et al, 1996; Zlotta et al, 1997a, 1997b), and this has led to the development of other less toxic but effective biological response modifiers. A nonviable mycobacterial cell wall extract (MCWE, US Patent No. 4744 984) derived from Mycobacterium phlei (M. phlei) has been shown to have anti-cancer activity. Intravesical therapy with MCWE formulated as a mineral oil emulsion (Regression ${ }^{\circledR}$, Bioniche, London, Ontario, Canada) has been shown to reduce cancer burden in orthotopic and heterotopic murine bladder cancers (Kadhim et al, 1993; Chin et al, 1996) and in patients with carcinoma in situ of the bladder (Morales and Chin, 1997).

MCWE is derived from $M$. phlei, a Gram-positive microorganism that is not a recognized pathogen for fish, amphibia, birds and mammals. This ubiquitous mycobacteria can be found in soil, on plants and in drinking water (Mallick et al, 1985; Papapetropoulou et al, 1997). MCWE is a partially delipidated and

Received 16 March 1998

Revised 16 June 1998

Accepted 16 June 1998

Correspondence to: NC Phillips, Bioniche Inc., 383 Sovereign Road, London, Ontario, Canada N6M 1 A3 deproteinized macromolecular complex composed primarily of carbohydrates, peptides and lipids. These molecules form the basis of the two major components of the cell wall, peptidoglycan and glycolipid (Chin et al, 1996). Although the mechanism of action of MCWE against bladder cancer is unknown, $M$. phlei has been reported to be a potent immunostimulator active against viral and parasitic infections (Mallick et al, 1985; Tewari et al, 1996).

M. phlei mycobacterial cell complex (MCC) is a cell wall composition wherein the mycobacterial DNA is preserved and complexed on the cell wall surface. We have found that MCC preparations contain approximately $5-10 \%$ of $M$. phlei-derived DNA, primarily in the form of short oligonucleotides (Filion et al, 1997). We have found that MCC has the ability to induce in vitro and in vivo the synthesis of a number of human and mouse cytokines (Filion et al, 1998). Because of the reported anti-cancer activity of interleukin 12 (IL-12) towards some cancer cell lines (Izquierdo et al, 1996; Stine et al, 1996) and the stimulatory activity of granulocyte-macrophage colony-stimulating factor (GM-CSF) on bladder cancer cell proliferation (Hawkyard et al, 1993), we felt it appropriate to determine whether MCC could induce the synthesis of these anti- and procancer cytokines by bladder cancer cells. We have also determined whether MCC could induce IL-6, which has been shown to function either as a growth factor (Okamato et al, 1997) or as an antiproliferative factor for bladder cancer lines (Alexandroff et al, 1997).

In this report we have (a) evaluated the ability of MCC to induce the synthesis of IL-6, IL-12 and GM-CSF by human HT-1197 and HT-1376 bladder cancer cells, and (b) determined whether MCC possesses direct cytostatic or cytotoxic activity towards these cancer cells. Our results show that MCC does not have the 
capacity to induce the synthesis of IL-12, IL-6 or GM-CSF by bladder cancer cells. However, MCC is a potent inducer of IL-12 and IL-6, and a poor inducer of GM-CSF synthesis by monocytes and macrophages. Furthermore, we show that MCC is able to directly inhibit the proliferation of HT-1197 and HT-1376 transitional cell carcinoma. MCC does not appear to be directly toxic towards these cancer cells: it does, however, induce apotosis. We found that M. phlei DNA associated with MCC is responsible for the induction of apoptosis. Our results indicate that MCC may possess a direct action against human bladder cancer cells after intravesical administration by inducing apoptosis, and an indirect action by stimulating cancer-infiltrating monocytes/macrophages to synthesize IL-12.

\section{MATERIALS AND METHODS}

\section{Cells}

HT-1197 and HT-1376 are cancer cell lines developed from anaplastic transitional cell carcinomas of the bladder taken from a 44-year-old Caucasian man (grade 4) and a 58-year-old Caucasian woman (grade 3) respectively (Rasheed et al, 1977). HT-1197 and HT-1376 cells were obtained from the American Type Tissue Culture Collection (ATCC; Rockville, MD, USA) and were grown in modified Eagle medium (MEM) supplemented with non-essential amino acids and vitamins and containing $10 \%$ fetal calf serum (FCS) (MEM-FCS; all from Gibco Life Science, Burlington, Ontario, Canada). Human monocytic THP-1 cells and murine monocytic RAW 264.7 cells obtained from the ATCC were cultured in RPMI-1640 medium supplemented with 10\% FCS, $2 \mathrm{~mm}$ L-glutamine and $20 \mathrm{~mm}$ Hepes (all from Gibco Life Science). Murine macrophages were obtained from female CD1 mice injected i.p. with $1.5 \mathrm{ml}$ sterile Brewer's thioglycolate broth (Difco, Detroit, MI, USA). The peritoneal exudate ( $>85 \%$ macrophages) was harvested at day 4 , washed by centrifugation in Hanks' balanced salt solution (HBSS) and seeded in 6-well flat bottom microplates at $1.0 \times 10^{6}$ cells $\mathrm{ml}^{-1}$ in the medium described for monocytes. The cells were allowed to adhere for $18 \mathrm{~h}$ at $37^{\circ} \mathrm{C}$ in an atmosphere of $5 \%$ carbon dioxide, after which non-adherent cells were removed by gentle washing with warm medium. Murine spleen cells were prepared by gentle teasing through sterile stainless-steel screens. Cell suspensions were layered on LympholyteM cell separation media (CedarLane, Hornby, Ontario, Canada) and centrifuged at 2200 r.p.m. for $30 \mathrm{~min}$ to remove red blood cells and dead cells. The cells were cultured in the culture medium described above. All cells were cultured at $37^{\circ} \mathrm{C}$ in an atmosphere of $5 \%$ carbon dioxide.

\section{Cytokine analysis}

Cells were seeded at $1 \times 10^{6}$ cells $\mathrm{ml}^{-1}$ in 6-well flat-bottomed tissue culture plates and treated with different concentrations of MCC for $48 \mathrm{~h}$. Human (h) and murine (m) IL-6, IL-12 and GMCSF synthesis was measured after $48 \mathrm{~h}$ by means of commercial enzyme-linked immunosorbent assay (ELISA) (all from BioSource, Camarillo, CA, USA, except murine GM-CSF which was from R\&D Systems, Minneapolis, MN, USA). The ELISA sensitivities were: $8 \mathrm{pg} \mathrm{ml}^{-1}$ for mIL-6, $2 \mathrm{pg} \mathrm{ml}^{-1}$ for $\mathrm{mIL}-12$, $1 \mathrm{pg} \mathrm{ml}^{-1}$ for mGM-CSF, $104 \mathrm{fg} \mathrm{ml}^{-1}$ for hIL-6, $1 \mathrm{pg} \mathrm{ml}^{-1}$ for hIL-12 and $1 \mathrm{pg} \mathrm{ml}^{-1}$ for hGM-CSF.

\section{Proliferation assay}

HT-1197 and HT-1376 cells were incubated in $1.0 \mathrm{ml}$ MEM-FCS at $3 \times 10^{5}$ cells in six-well flat-bottomed tissue culture plates with MCC, Escherichia coli 011:B4 lipopolysaccharide (LPS; SigmaAldrich Canada, Oakville, Ontario, Canada) or recombinant hIL-12 (R\&D Systems) for $20 \mathrm{~h}$ at $37^{\circ} \mathrm{C}$ in an atmosphere of $5 \%$ carbon dioxide. Cellular growth was measured by determination of dimethylthiazoldiphenyltetrazolium bromide (MTT) reduction (Mosman et al, 1983). Briefly, $100 \mu \mathrm{l}$ of MTT (Sigma-Aldrich) dissolved in PBS at $5 \mathrm{mg} \mathrm{ml}^{-1}$ was added to wells and incubated at $37^{\circ} \mathrm{C}$ for $4 \mathrm{~h}$. Acid-isopropanol $(1.0 \mathrm{ml}$ of $0.04 \mathrm{~N}$ hydrochloric acid in isopropanol) was then added, and reduced MTT was measured at a wavelength of $570 \mathrm{~nm}$.

\section{MCC toxicity determination}

HT-1197 or HT-1376 cells were incubated in $1.0 \mathrm{ml}$ of MEM-FCS at $3 \times 10^{5}$ cells in 6 -well flat-bottomed tissue culture plates with MCC for $48 \mathrm{~h}$. Lactate dehydrogenase (LDH) activity in the supernatant was used as an indicator of cell death, and was determined by means of a commercial kit (Sigma-Aldrich). Total LDH activity was determined by incubating macrophages in $1.0 \% \mathrm{v} / \mathrm{v}$ Triton $\mathrm{X}$ 100 in water to induce lysis, followed by vigorous agitation (Filion and Phillips, 1997).

\section{Analysis of apoptosis}

HT-1197 or HT-1376 cells were incubated in $1.0 \mathrm{ml}$ MEM-FCS at $3 \times 10^{5}$ cells in six-well flat-bottomed tissue culture plates with $1 \mu \mathrm{g} \mathrm{ml}^{-1}$ of MCC or with $1 \mathrm{ng} \mathrm{m} \mathrm{m}^{-1}$ of IL-12 for up to $48 \mathrm{~h}$. After incubation, non-adherent cells in the supernatant were collected by centrifugation at $200 \mathrm{~g}$ for $10 \mathrm{~min}$. The pellet or remaining adherent cells were lysed with $0.5 \mathrm{ml}$ of hypotonic lysing buffer, pH 7.5 (10 mM Tris buffer, $1 \mathrm{~mm}$ EDTA, 0.2\% Triton X-100). The lysates were centrifuged at $13000 \mathrm{~g}$ for $10 \mathrm{~min}$ and the supernatants containing fragmented DNA were precipitated overnight at $-20^{\circ} \mathrm{C}$ in $50 \%$ isopropanol and $0.5 \mathrm{M}$ sodium chloride. The precipitates were collected by centrifugation and analysed by electrophoresis in $0.7 \%$ agarose gels for $3 \mathrm{~h}$ at $100 \mathrm{~V}$ (Newell, 1990). Apoptosis was also determined by an ELISA (Calbiochem, Cambridge, MA, USA) that detects nuclear mitotic apparatus protein (NuMA) released from cells undergoing induced apoptosis (Miller et al, 1993). Briefly, HT-1197 or HT-1376 cells were treated as described above with MCC or with DNA extracted from MCC. Media from the cell cultures was removed at 0, 3, 6, 24 and/or $48 \mathrm{~h}$, centrifuged at $200 \mathrm{~g}$ for $10 \mathrm{~min}$ and the supernatant was collected. The supernatant $(100 \mu \mathrm{l})$ was used for the determination of NuMA protein release by ELISA.

\section{Isolation and treatment of DNA from MCC}

Mycobacterial DNA was purified from MCC by conventional phenol extraction and ethanol precipitation (Moore, 1995). MCC or DNA extracted from MCC was incubated with $1 \mathrm{U}$ of DNAse I (Gibco Life Sciences) for $1 \mathrm{~h}$ at $25^{\circ} \mathrm{C}$ in $20 \mathrm{~mm}$ tris- $\mathrm{HCl}$ ( $\mathrm{pH} 8.4$ ), $2 \mathrm{~mm}$ magnesium chloride and $50 \mathrm{~mm}$ potassium chloride. DNAse I was inactivated by the addition of EDTA (final concentration $2.5 \mathrm{~mm}$ ) and the reaction mixture was heated for 10 min at $65^{\circ} \mathrm{C}$. Digestion was confirmed by electrophoresis in $0.7 \%$ agarose gels for $3 \mathrm{~h}$ at $100 \mathrm{~V}$. 


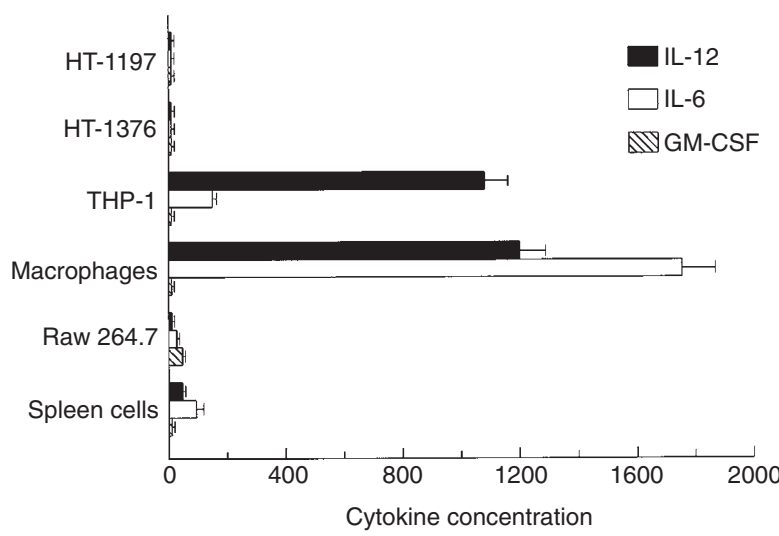

Figure 1 MCC induces IL-6 and IL-12 synthesis only in monocytes and macrophages. Human bladder cancer cell lines HT-1197 and HT-1376, human monocytic THP-1 cells, murine monocytic RAW 264.7 cells, murine macrophages or murine spleen cells were incubated at $1.0 \times 10^{6} \mathrm{cells} \mathrm{m}^{-1}$ with $1.0 \mu \mathrm{g} \mathrm{ml}^{-1}$ of MCC for $48 \mathrm{~h}$. IL-6, IL-12 and GM-CSF in the supernatant were measured after $48 \mathrm{~h}$ by the appropriate ELISA. The results shown are the means \pm s.d. of three independent experiments

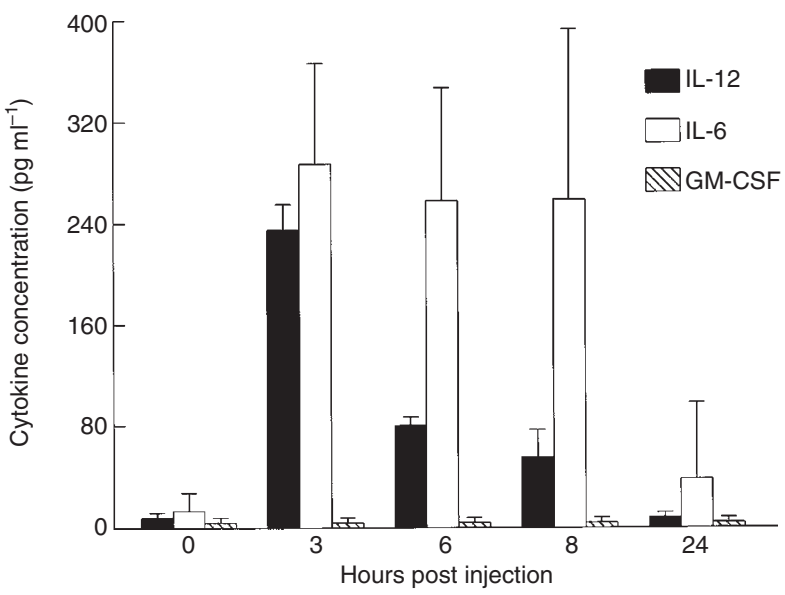

Figure 2 MCC induces the synthesis of IL- 6 and IL-12 without GM-CSF in mice. Groups of five mice were injected i.p. with MCC $\left(50.0 \mathrm{mg} \mathrm{kg}^{-1}\right)$. Murine IL-6, IL-12 and GM-CSF in the serum were quantified at 0, 3, 6, 8 and $24 \mathrm{~h}$ after injection by the appopriate ELISA. The results shown are the means \pm s.d. of two independent experiments

\section{RESULTS}

\section{Effect of MCC on cytokine synthesis}

A number of cytokines are known to influence the regression or the progression of cancer. IL-12 has been shown to have potent anti-cancer activity by stimulating natural killer (NK) cells or Tcells, and/or in blocking angiogenesis (Voest et al, 1995; Zitvogel and Lotze, 1995; Stern et al, 1996) whereas GM-CSF has the capacity to stimulate the unwanted proliferation of low-grade bladder neoplasms (Hawkyard et al, 1993). IL-6 has the capacity to stimulate the growth of bladder cancer cells (Okamoto et al, 1997) or to inhibit their proliferation (Alexandroff et al, 1997). It has also been shown that bladder cancer cells are able to secrete cytokines (De Reijke et al, 1993; Bevers et al, 1997). We have, therefore, evaluated whether bladder cancer cells or immune effector cells have the ability to synthesize IL-12, IL-6 or GM-C SF in response to MCC. As shown in Figure 1, IL-12, IL-6 and

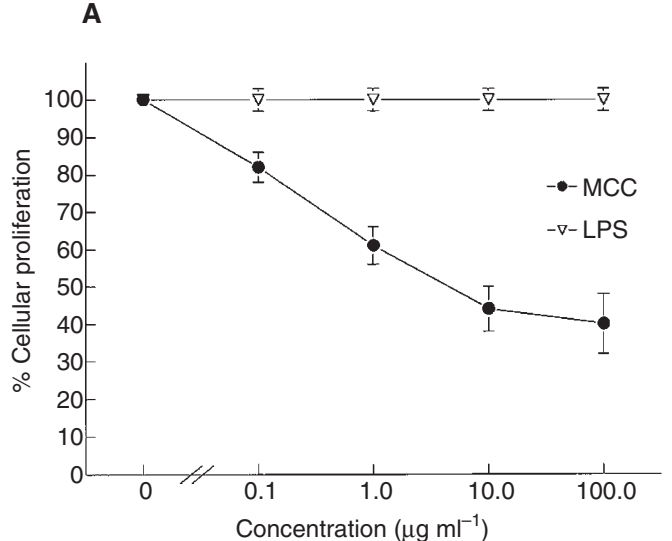

B

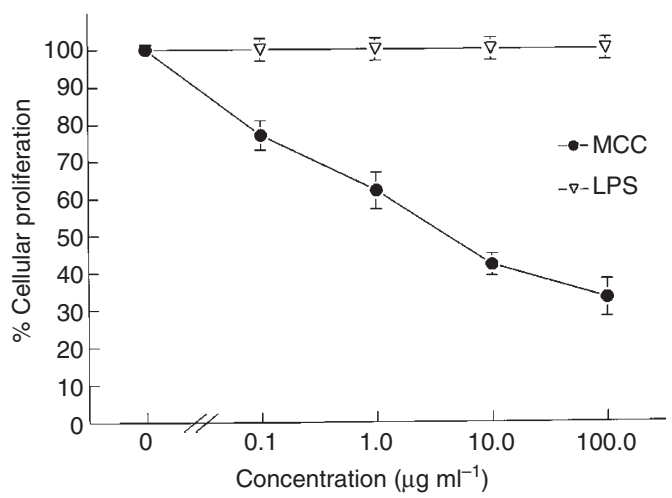

Figure 3 MCC inhibits the cellular proliferation of human bladder cancer cells. HT-1197 (A) and HT-1376 (B) cells were incubated at $3.0 \times 10^{5}$ cells $\mathrm{ml}^{-1}$ with different concentrations of MCC or LPS for $24 \mathrm{~h}$ at $37^{\circ} \mathrm{C}, 5 \%$ carbon dioxide. Cellular proliferation was measured by determination of MTT reduction as described in the Materials and methods section. The results shown are the means \pm s.d. of three independent experiments

GM-CSF are not produced by HT-1197 and HT-1376 bladder cancer cells in response to $1.0 \mu \mathrm{g} \mathrm{ml}^{-1}$ of MCC. However, at this concentration, human THP-1 monocytes and murine macrophages are able to produce significant amounts of IL-12 and IL-6 in response to MCC treatment. Only murine RAW 264.7 cells were able to synthesize GM-CSF. The i.p. administration of MCC to female CD1 mice did not result in the synthesis of GM-CSF, but did, however, induce the synthesis of IL-12 and IL-6 (Figure 2). Similar results were obtained when MCC was administered i.v. (data not shown).

\section{Inhibition of cancer cell proliferation by MCC}

The ability of MCC to directly influence the proliferation of HT1197 and HT-1376 bladder cancer cells was investigated. MCC is able to inhibit the cellular proliferation of these bladder cancer cells in a dose-dependent manner, whereas the control immunostimulant LPS is without activity (Figure 3). IL-12 has been shown to reduce the proliferative rate of several cancer cell lines (Izquierdo et al, 1996; Stine et al, 1996). IL-12 does not inhibit the proliferation of either HT-1197 or HT-1376 bladder cancer cells in the dose range $0.1-100 \mathrm{ng} \mathrm{ml}^{-1}$ (data not shown). To explain this growth inhibition, we have evaluated whether MCC is directly cytotoxic towards these cancer cells. Toxicity is characterized by the loss of plasma membrane integrity and release of the 


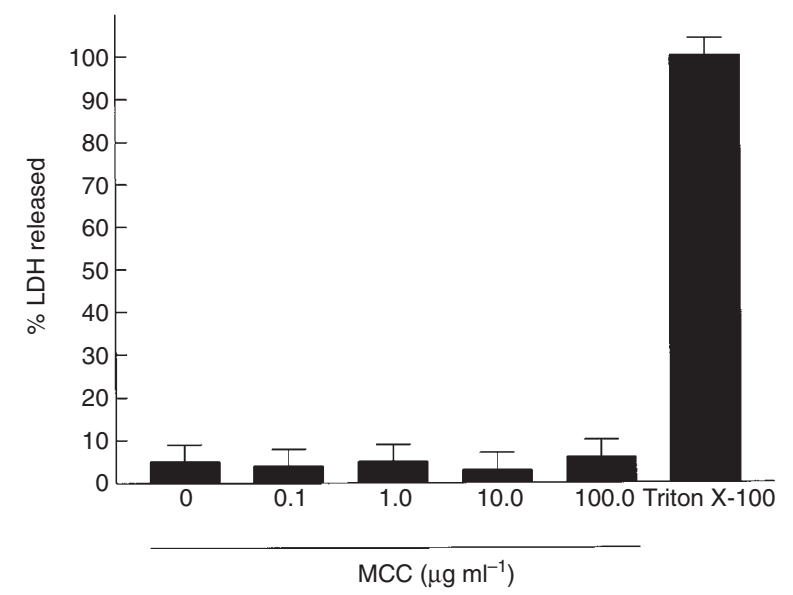

Figure $4 \mathrm{MCC}$ is not cytotoxic towards human bladder cancer cells. HT-1376 cells were incubated at $3.0 \times 10^{5}$ cells ml-1 with the indicated concentrations of $\mathrm{MCC}$ for $48 \mathrm{~h}$ at $37^{\circ} \mathrm{C}, 5 \%$ carbon dioxide. Toxicity was determined by the release of LDH activity into the supernatant. Total LDH activity was determined by incubating the cells with $1.0 \%(\mathrm{v} / \mathrm{v})$ Triton X-100.

The results shown are the means \pm s.d. of three independent experiments

cytoplasmic enzyme LDH (Wyllie et al, 1980). The release of LDH into the culture supernatant has been used as an indicator of cell death (Phillips et al, 1996), and human bladder cancer cells have been shown to release $\mathrm{LDH}$ when treated with cytotoxic agents (Rahman, 1994). As shown in Figure 4, MCC is not cytotoxic towards HT-1376 cells, as determined by the release of LDH into the culture supernatant. Similar results were obtained with HT-1197 cells (data not shown).

\section{Induction of apoptosis by MCC}

The lack of a direct cytotoxicity of MCC towards HT-1197 and HT-1376 cancer cells in combination with the antiproliferative activity suggested that MCC is an apoptosis inducer. Apoptosis, or programmed cell death, is associated with nuclear DNA fragmentation, the release of nuclear matrix proteins such as NuMA and the loss of cell-substrate contact (Wyllie et al, 1980; Newell et al, 1990; Miller et al, 1993). The induction of apoptosis was demonstrated by visualization of nucleosome-sized DNA fragments on agarose gel electrophoresis and by the release of NuMA proteins. MCC at $1.0 \mu \mathrm{g} \mathrm{ml}^{-1}$ was able to induce apoptosis in both HT-1197 and HT-1376 bladder cancer cells. Nucleosome-sized DNA fragments characteristic of apoptosis were detected in detached HT1197 and HT-1376 bladder cancer cells after treatment with MCC (Figure 5) MCC also induced the release of NuMA proteins in a dose-related manner (Figure 6A). The release of NuMA increased gradually from $3 \mathrm{~h}$ to $48 \mathrm{~h}$; a concentration of $100 \mu \mathrm{g} \mathrm{ml}^{-1} \mathrm{MCC}$ being the most effective (Figure 6B and C). IL-12, which has been shown to induce apoptosis of several cancer cell lines (Stine et al, 1996), was unable to induce apoptosis in HT-1197 and HT1376 bladder cancer cells, as demonstrated by an absence of nucleosome-sized DNA fragments on agarose gel electrophoresis (Figure 5).

We have previously shown that MCC contains approximately 5-10\% of M. phlei-derived DNA (Filion et al, 1997). We have evaluated whether the DNA associated with MCC can induce apoptosis of bladder cancer cells. DNA extracted from MCC is able to induce the release of NuMA from HT-1376 cells, but to a lesser extent than MCC (Figure 7). Treatment of MCC or M. phlei DNA extracted from MCC by DNAse I, which has the capacity to degrade single- and double-stranded DNA, significantly inhibits the release of NuMA proteins (Figure 7), indicating that $M$. phlei DNA plays a pivotal role in the induction of apoptosis in HT-1376 cancer cells. Similar results were obtained with HT-1197 cells (data not shown).

\section{DISCUSSION}

In the present study, we have shown that MCC can act directly on bladder cancer cells by inhibiting cellular proliferation through the
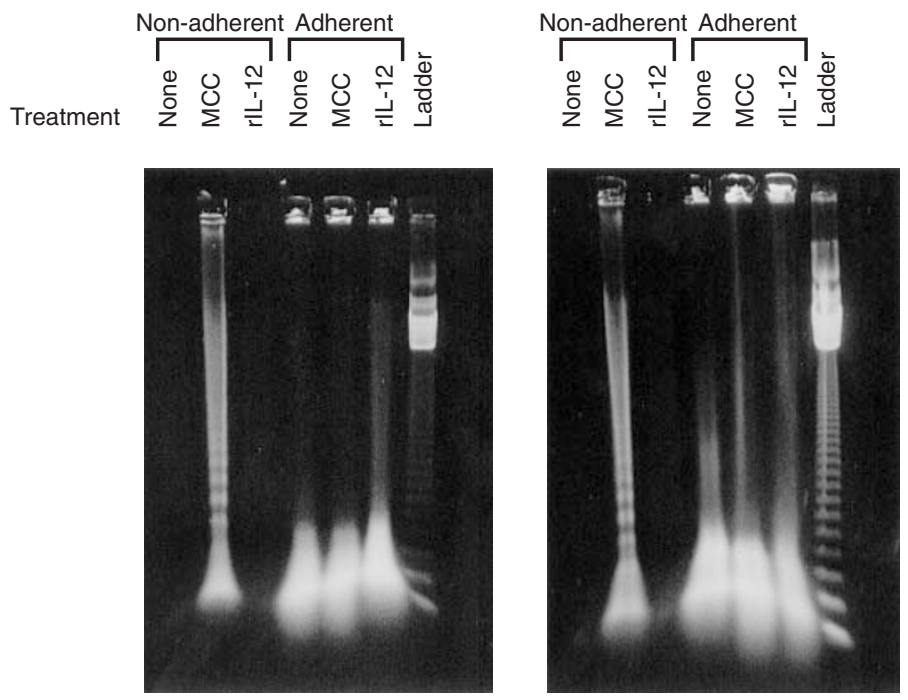

HT-1197

HT-1376

Figure 5 MCC induces nuclear DNA fragmentation of human bladder cancer cells. HT-1197 and HT- 1376 cells were incubated at $3.0 \times 10^{5}$ cells ml-1 with $1.0 \mu \mathrm{g} \mathrm{ml}^{-1}$ of $\mathrm{MCC}$ or with $1.0 \mathrm{ng} \mathrm{ml}^{-1}$ of IL-12 at $37^{\circ} \mathrm{C}, 5 \%$ carbon dioxide. Adherent and non-adherent cells were lysed $48 \mathrm{~h}$ later. Cellular DNA was extracted precipitated and analysed by electrophoresis in $0.7 \%$ agarose gels for $3 \mathrm{~h}$ at $100 \mathrm{~V}$ as described in the Materials and methods section. A 123-bp DNA ladder was used to evaluate the molecular weight of nucleosome-sized DNA. The results shown are for one experiment out of three; all give similar results 


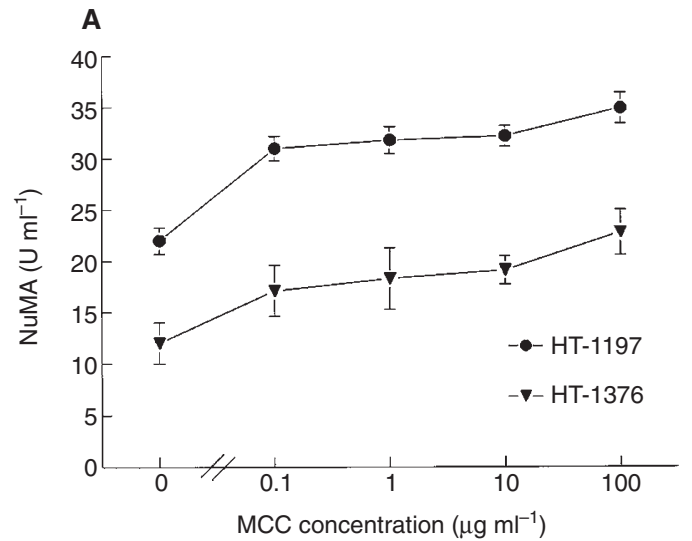

B

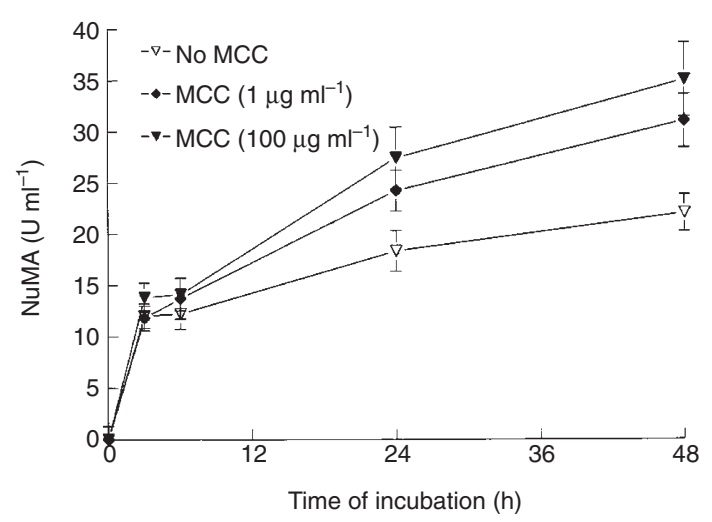

C

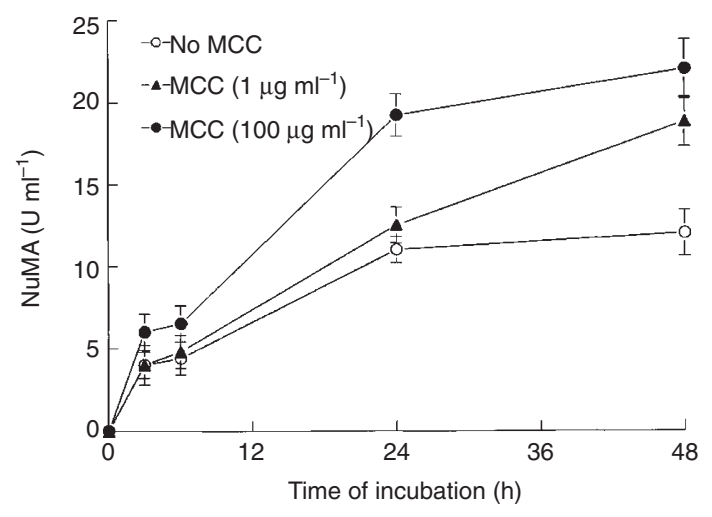

Figure 6 MCC induces the release of NuMA from human bladder cancer cells. HT-1197 and HT-1376 cells were incubated at $3.0 \times 10^{5}$ cells $\mathrm{ml}^{-1}$ with MCC at $37^{\circ} \mathrm{C}, 5 \%$ carbon dioxide. In (A), the release of NuMA from the cells into the supernatant was detected by ELISA during incubation with different concentrations of MCC for $48 \mathrm{~h}$. In (B), the release of NuMA from HT-1197 cells, and in (C) the release of NuMA from HT-1376 cells into the supernatant, was determined at $0,3,8,24$ and $48 \mathrm{~h}$ after treatment with $1 \mu \mathrm{g} \mathrm{ml}^{-1}$ or $100 \mu \mathrm{g} \mathrm{ml}^{-1}$ of MCC. The results shown are the means \pm s.d. of three independent experiments

induction of apoptosis. MCC does not have the ability to induce the synthesis of anti- (IL-12) or procancer (GM-CSF) cytokines by bladder cancer cells but does have the ability to induce the synthesis of significant amounts of the anti-cancer cytokine IL-12 by monocytes and macrophages either in vitro or in vivo. Monocytes and macrophages have been shown to be present in the bladder wall of healthy individuals and have been shown to

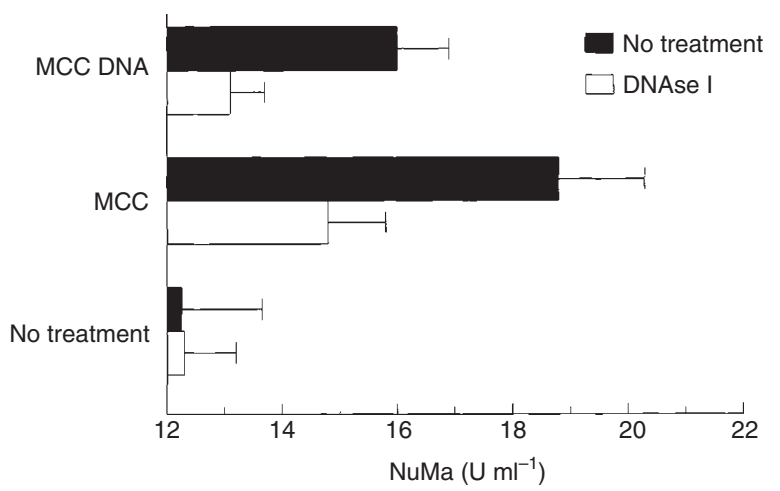

Figure 7 DNA extracted from MCC induces the release of NuMA. HT-1376 cells $\left(3.0 \times 10^{5}\right.$ cells $\left.\mathrm{ml}^{-1}\right)$ were incubated for $48 \mathrm{~h}$ at $37^{\circ} \mathrm{C}, 5 \%$ carbon dioxide with MCC or DNA purified from MCC $\left(1 \mu \mathrm{g} \mathrm{ml}^{-1}\right)$. In some experiments, MCC or DNA purified from MCC were treated by DNAse I $(1 \mathrm{U})$ as described in the Materials and methods section before their addition to HT-1376 cells. After $48 \mathrm{~h}$, supernatants were collected $(100 \mu \mathrm{l})$ and the release of NuMA released was quantified by ELISA as described in the Materials and methods section. The results shown are the means \pm s.d. of two independent experiments

accumulate around tumour islands in patients with bladder cancer (El-Demiry et al, 1986; Ioachim-Velogiammi et al, 1994). IL-12 synthesized by these monocytes and macrophages may make a significant contribution to the overall anti-cancer activity of MCC. IL-12 has been shown to possess potent anti-cancer activity after systemic or local administration in mice bearing a variety of malignancies including melanomas, carcinomas, sarcomas, transitional bladder carcinoma and lymphomas (Brunda et al, 1993; Nastala et al, 1994; Noguchi et al, 1995; Zou et al, 1995, Chen et al, 1997). IL-12 plays a role in the development of T-helper type-1 lymphocytes, stimulates $\gamma$-interferon (IFN- $\gamma$ ) synthesis, blocks angiogenesis at sites of cancer growth and enhances NK cell and cytotoxic T-cell activity (Voest et al, 1995; Stern et al, 1996; Zitvogel and Lotze, 1996). Although IL-12 can also exert a direct effect on some cancer cells by inhibiting cellular proliferation through the induction of apoptosis (Stine et al, 1996), this does not appear to be the case for the two bladder cancer cell lines used in our study. The addition of recombinant human IL-12 to HT-1197 and HT-1376 bladder cancer cells had no direct effect on cellular proliferation, and apoptosis was not induced by IL-12.

GM-CSF has been shown to induce the proliferation of bladder cancer cells (Hawkyard et al, 1993). The results of our study show that MCC does not induce, either in vitro or in vivo, the synthesis of significant quantities of GM-CSF. BCG possesses the ability to up-regulate the synthesis of IL-6 in bladder cancer cells (Esuvaranathan et al, 1995; Sasaki et al, 1997). The role of IL-6 in bladder cancer outcome is, however, unclear. IL-6 has been shown to function either as a growth factor for bladder cancer lines (Okamoto et al, 1997), or as an antiproliferative factor (Alexandroff et al, 1997). We have found that although MCC at 1.0 $\mu \mathrm{g} \mathrm{ml}^{-1}$ does not possess the ability to induce the synthesis of IL- 6 by HT-1197 and HT-1376 bladder cancer cells, it does have the ability to induce IL- 6 by monocytes and macrophages either in vitro or in vivo.

BCG has been shown to have antiproliferative effects on human bladder cancer cells in vitro in the absence of any immune effector cells (Pryor et al, 1995a, 1995b). Similar antiproliferative effects of both heat-killed and viable BCG on a panel of human bladder transitional cell carcinoma cell lines have also been described 
(Jackson et al, 1994). However, the mechanism of cellular growth inhibition has not been identified in these studies (Jackson et al, 1994; Pryor et al, 1995a). Sasaki et al (1997) have shown that the ability of BCG to inhibit the growth of T24 cells was not related to the induction of apoptosis. Other groups have reported an indirect induction of apoptosis in bladder cancer cells by BCG. Shemtov et al (1995) have shown that the human bladder cancer cell line T24 can undergo apoptosis after contact with lymphocyte-activated killer cell (LAK cells), whereas Kudoh et al (1997) have found that BCG-activated lymphocytes are able to induce apotosis of T24 cells via cytokine synthesis. In this study, we have found that the antiproliferative activity of MCC was mediated by the direct induction of apoptosis of human bladder cancer cells and not by a cytotoxic effect. To our knowledge, the present study is the first demonstration of the ability of a mycobacterial cell wall preparation to directly induce apoptosis in cancer cells. We have additionally demonstrated that the apoptosis induced by MCC is related to the presence of mycobacterial DNA in the preparation, and that $M$. phlei DNA has intrinsic apoptosis-inducing activity.

Apoptosis plays an important role in the activity of many anticancer chemotherapeutic agents and in their effectiveness in the treatment of cancer (Dive et al, 1992). It has been shown, however, that bladder carcinomas are resistant to a number of anti-cancer drugs (Lamm et al, 1995). Our data show that MCC not only directly induces apoptosis in HT-1197 bladder cancer cells, which are sensitive to doxorubicin, but also directly induces apoptosis in HT-1376 bladder cancer cells, which have been shown to be resistant to several apoptosis-inducing drugs such as cisplatin and mitomycin C (Kawasaki et al, 1996; Mizutani et al, 1997). Chemotherapy of bladder cancer has been shown to be effective in lowgrade cancers, whereas immunotherapy with BCG appears to be optimally effective in higher grade cancers (Lamm, 1995). Although highly effective regardless of tumour grade, BCG treatment is preferably reserved for the most aggressive cancer because of its safety profile (Lamm, 1995). MCC, which appears to possess both a chemotherapeutic-like action against human bladder cancer cells by inducing apoptosis and an indirect BCG-like action by stimulating immune effector cells, has significant promise for the treatment of both low-grade and high-grade bladder cancers. Because mycobacterial cell wall extracts do not contain live bacteria, their safety profile is better (Morales and Chin, 1997). Further studies investigating the role of apoptosis and IL-12 synthesis induced by MCC using in vivo animal models will be required to clarify the mechanisms implicated in the anti-cancer activity of MCC. MCC and M. phlei DNA associated with MCC are currently being analysed to determine their proapoptotic activity on a number of other bladder cancer cell lines and on freshly derived primary cultures of human bladder carcinoma cells.

\section{REFERENCES}

Alexandroff AG, Black J, Esuvaranathan K and James K (1997) Antiproliferative effect of IL- 6 on transitional cell carcinoma of the bladder. Insight into mechanisms of bacillus Calmette-Guérin in immunotherapy. Biochem Soc Trans 25: $270 \mathrm{~S}$

Bevers RF, de Boer EC, Kruth LH and Schamhart DH (1997) Effects of isoniazid on the proliferation and cytokine production of bladder cancer cells in vitro induced by bacille Calmette-Guérin. Br J Urol 80: 35-39

Brunda MJ, Luistro L, Warrier RR, Wright RB, Hubbard BR, Murphy M, Wolf SF and Gately MK (1993) Antitumour and antimetastatic activity of interleukin-12 against murine tumors. J Exp Med 178: 1223-1230
Chen L, Chen D, Block E, O'Donnell M, Kufe DW and Clinton SK (1997) Eradication of murine bladder carcinoma by intratumoral injection of a bicistronic adenoviral vector carrying cDNAs for the IL-12 heterodimer and its inhibition by the IL-12 p40 subunit homodimer. J Immunol 159: 351-359

Chin JL, Kadhim SA, Batislam E, Karlik SJ, Garcia BM, Curtis Nickel J and Morales A (1996) Mycobacterium cell wall: an alternative to intravesical bacillus Calmette Guerin (BCG) therapy in orthotopic murine bladder cancer. J Urol 156: 1189-1193

De Reijke TM, Vos PC, de Boer EC, Bevers RF, de Munick Keizer, Kurth KH and Schambart DH (1993) Cytokine production by the human bladder carcinoma cell line T24 in the presence of bacillus Calmette-Guérin (BCG). Urol Res 21: 349-352

Dive C, Evans CA and Whetton AD (1992) Induction of apoptosis: new targets for cancer chemotherapy. Semin Cancer Biol 3: 417-427

El-Demiry MIM, Hargreave TB, Busuttil A, James K and Chrisholm GD (1986) Immunohistochemical identification of lymphocyte subsets and macrophages in normal human urothelium using monoclonal antibodies. Br J Urol $\mathbf{5 8}$ : 436-442

Esuvaranathan K, Alexandroff AG, McIntyre M, Jackson AM, Prescott S, Chisholm GD and James K (1995) Interleukin-6 production by bladder tumors is upregulated by BCG immunotherapy. J Urol 154: 572-575

Filion MC and Phillips NC (1997) Toxicity and immunomodulatory activity of liposomal vectors formulated with cationic lipids toward immune effector cells. Biochim Biophys Acta 1329: 345-356

Filion MC, Lépicier P and Phillips NC (1997) Mycobacterium phlei cell wall complex, a new antitumoral agent, induces IL-12 synthesis by monocytes/macrophages. Blood 90: 58b

Filion MC et al (1998) (manuscript in preparation)

Hawkyard SJ, Jackson AM, Prescott S, James K and Chisholm GD (1993) The effect of recombinant cytokines on bladder cancer cells in vitro. J Urol 150: 514-518

Ioachim-Velogianni E, Stavropoulos NE, Kitsiou E, Stefanaki S and Agnantis NJ (1994) HLA-DR antigen expression subsets in transitional cell carcinoma of the urinary bladder. An immunohistological study in frozen sections. J Pathol 174: $183-189$

Izquierdo MA, Degen D, Sypek JP and Von Hoff DD (1996) Antiproliferative effects of IL-12 on human tumor colony-forming units taken directly from patients. Anticancer Drugs 7: 275-280

Jackson AM, Alexandroff AB, Fleming D, Prescott S, Chisholm GD, Carter GD and James K (1994) Bacillus Calmette-Guérin (BCG) organisms directly alter the growth of bladder tumour cells. Int J Oncol 5: 697-703

Kadhim SA, Chin JL, Batislam E, Karlick S, Garcia BM, Curtis Nickel J and Morales A (1993) Modification of intravesical Bacillus Calmette Guerin (BCG) therapy in orthotopic murine bladder tumor: use of mycobacterial cell wall extract (MCWE). J Urol 149: A225

Kawasaki T, Tomita Y, Bilim V, Takeda M, Takahashi K and Kumanishi T (1996) Abrogation of apoptosis induced by DNA-damaging agents in human bladdercancer cell lines with $p 21 / \mathrm{WAF} 1 / \mathrm{CIP} 1$ and/or $p 53$ gene alterations. Int $J$ Cancer 68: 501-505

Kudoh S, Liu XX, Mori K and Suzuki T (1997) BCG-activated lymphocytes induce the death of bladder cancer cell via apoptosis in vitro. Br J Urol 80S2: 40

Lagranderie MRR, Balazuc A-M, Deriaud E, Leclerc CD and Gheorghiu M (1996) Comparison of immune responses of mice immunized with five different Mycobacterium bovis BCG vaccine strains. Infect Immunol 64: 1-9

Lamm DL (1995) BCG in perspective: advances in the treatment of superficial bladder cancer. Eur Urol 27S1: 2

Lamm DL, van der Meijden AD and Morales A (1992) Incidence and treatment of complications of bacillus Calmette-Guérin intravesical therapy in supperficial bladder cancer. J Urol 147: 596-600

Lamm DL, Riggs DR, Traynelis CL and Nseyo UN (1995) Failure of intravesical chemotherapy prophylaxis in superficial transitional cell carcinoma of the bladder. J Urol 153: 1444-1450

Mallick BB, Kishore S, Das SK and Garg A (1985) Non-specific immunostimulation against viruses. Comp Immunol Microbiol Infect Dis 8: 55-63

Miller T, Beausang LA, Meneghini M and Lidgard G (1993) Death-induced changes to the nuclear matrix: the use of anti-nuclear matrix antibodies to study agents of apoptosis. Biotechniques 15: 1042-1047

Mizutani Y, Okada Y, Yoshida O, Fukumoto M and Bonavida B (1997) Doxorubicin sensitizes human bladder carcinoma cells to Fas-mediated cytotoxicity. Cancer 79: $1180-1189$

Morales A (1984) Long term results of BCG therapy for bladder cancer. J Urol 132 : $457-459$

Morales A and Chin JL (1997) Mycobacterial cell wall (MCW) as an alternative to BCG in the treatment of carcinoma-in-situ (CIS) of bladder: an efficacy study. J Urol 157: A214 
Mosman T (1983) Rapid colorimetric assay for cellular growth and survival: application to proliferation and cytotoxicity assays. J Immunol Methods $\mathbf{6 5}$ : 55-63

Nastala CL, Edington HD, McKinney TG, Tahara H, Nalesnik MA, Brunda MJ, Gately MK, Wolf SF, Schreiber RD, Stewart WT, Storkus J and Lotze MT (1994) Recombinant interleukin-12 (IL-12) administration induces tumor regression in association with interferon- $\gamma$ production. J Immunol 153 $1697-1706$

Newell MK, Haughn LJ, Maroun CR and Julius MH (1990) Death of mature T cells by separate ligation of CD4 and the T-cell receptor for antigen. Nature 347 : 286-288

Noguchi Y, Richards EC, Chen YT and Old LJ (1995) Influence of interleukin-12 on p53 peptide vaccination against established Meth A sarcoma. Proc Natl Acad Sci USA 92: 2219-2223

Okamoto M, Hattori K and Oyasu R (1997) Interleukin-6 functions as an autocrine growth factor in human bladder carcinoma cell lines in vitro. Int J Cancer $\mathbf{7 2}$ $149-154$

Papapetropoulou M, Tsintzou A and Vantarakis A (1997) Environmental mycobacteria in bottled table waters in Greece. Can J Microbiol 43: 499-502

Phillips NC, Gagné L, Ivanoff N and Riveau G (1996) Influence of phospholipid composition on antibody responses to liposome encapsulated protein and peptide antigens. Vaccine 14: 898-904

Pryor K, Stricker P, Russell P, Golovsky D and Penny R (1995a) Antiproliferative effects of bacillus Calmette-Guérin and interferon $\alpha 2 \mathrm{~b}$ on human bladder cancer cells in vitro. Cancer Immunol Immunother 41: 309-316

Pryor K, Goddard J, Goldstein D, Stricker P, Russell P, Govolsky D and Penny R (1995b) Bacillus Calmette-Guérin (BCG) enhances monocyte- and lymphocyte-mediated bladder tumour cell killing. Br J Cancer 71: 801-807

Rahman M (1994) In vitro effects of high energy shock wave alone and combined with anticancer drugs on human bladder cancer cells. Urol Int 53: 12-17

Rasheed S, Gardner MB, Rongey RW, Nelson-Rees A and Arnstein P (1977) Human bladder carcinoma: characterization of two new tumor cell lines and search for tumor viruses. J Natl Cancer Inst 58: 881-887

Sasaki A, Kudoh S, Mori K, Takahashi N and Suzuki T (1997) Are BCG effects against urinary bladder carcinoma cell line $\mathrm{T} 24$ correlated with apoptosis in vitro? Urol Int 59: 142-148
Shemtov MM, Cheng DL-W, Kong L, Shu W-P, Sassaroli M, Droller MJ and Liu BC-S (1995) LAK cell mediated apoptosis of human bladder cancer cells involves a pH-dependent endonuclease system in the cancer cell: possible mechanism of BGC therapy. J Urol 154: 269-274

Stern AS, Magram J and Presky DH (1996) Interleukin-12 an integral cytokine in the immune response. Life Sci 58: 639-654

Stine KC, Warren BA and Becton DL (1996) Apoptosis induced by interleukin-12 measured by DNA electrophoresis and in situ end labelling in leukemia. Ann NY Acad Sci 795: 420-421

Tewari AK, Sharma NN, Rao JR, Mishra AK and Das SK (1996) Effect of Mycobacterium phlei on the development of immunity to Babesia bigemina. Vet Parasitol 62: 223-230

Voest EE, Kenyon MN, O'Reilly MS, Truitt G, D'Amato RJ and Folkman J (1995) Inhibition of angiogenesis in vivo by interleukin 12. J Natl Cancer Inst 87: $581-586$

Wyllie SH (1980) Cell death: the significance of apoptosis. Int Rev Cytol 68 251-306

Zitvogel L and Lotze NH (1995) Role of interleukin-12 (IL-12) as an anti-tumor agent: experimental biology and clinical application. Res Immunol 146 628-638

Zlotta AR, Drowart A, Huygen K, De Bruyn J, Shekarsarai H, Decock M, Pirson M, Jurion F, Palfliet K, Denis O, Mascart F, Simon J, Schulman CC and Van Vooren JP (1997a) Humoral response against heat shock proteins and other mycobacterial antigens after intravesical treatment with bacille CalmetteGuérin (BCG) in patients with superficial bladder cancer. Clin Exp Immunol 109: $157-165$

Zlotta AR, Drowart A, Van Vorren JP, de Cook M, Pirson M, Palfliet K, Jurion F, Vanonckelen A, Simon J, Schulman CC and Huygen K (1997b) Evaluation and clinical significance of the $\mathrm{T}$ cell proliferative and cytokine response directed against the fibronectin binding antigen 85 complex of bacillus Calmette-Guérin during intravesical treatment of superficial bladder cancer. J Urol 157: 492-498

Zou JP, Yamamoto N, Fujii T, Takenaka H, Kobayashi M, Herrmann SH, Wolf SF, Fujiwara H and Hamaoka T (1995) Systemic administration of rIL-12 induces complete tumor regression and protective immunity: response is correlated with a striking reversal of suppressed interferon- $\gamma$ production by anti-tumor $\mathrm{T}$ cells. Int Immunol 7: 1135-1145 